\title{
Microchips and their Significance in Isolation of Circulating Tumor Cells and Monitoring of Cancers
}

\author{
Mehdi Sahmani $^{1}$, Mousa Vatanmakanian², Mehdi Goudarzi ${ }^{3}$, Naser Mobarra $^{4}$, \\ Mehdi Azad ${ }^{5 *}$
}

\begin{abstract}
In micro-fluid systems, fluids are injected into extremely narrow polymer channels in small amounts such as micro-, nano-, or pico-liter scales. These channels themselves are embedded on tiny chips. Various specialized structures in the chips including pumps, valves, and channels allow the chips to accept different types of fluids to be entered the channel and along with flowing through the channels, exert their effects in the framework of different reactions. The chips are generally crystal, silicon, or elastomer in texture. These highly organized structures are equipped with discharging channels through which products as well as wastes of the reactions are secreted out. A particular advantage regarding the use of fluids in micro-scales over macro-scales lies in the fact that these fluids are much better processed in the chips when they applied as micro-scales. When the laboratory is miniaturized as a microchip and solutions are injected on a micro-scale, this combination makes a specialized construction referred to as "lab-on-chip". Taken together, micro-fluids are among the novel technologies which further than declining the costs; enhancing the test repeatability, sensitivity, accuracy, and speed; are emerged as widespread technology in laboratory diagnosis. They can be utilized for monitoring a wide spectrum of biological disorders including different types of cancers. When these microchips are used for cancer monitoring, circulatory tumor cells play a fundamental role.
\end{abstract}

Keywords: Microchips - cancer - circulating tumor cells - monitoring

Asian Pac J Cancer Prev, 17 (3), 879-894

\section{Introduction}

As the genes and proteins are the fundamental components of biological systems, they are considered as central focus of advances in molecular and cellular biology. Recent progresses in genomics and proteomics have led to the advent of high-throughput screening methods such as microchips, or "lab on a chip (LOC) structures, or micro total analysis system ( $\mu$ TAS) (Figeys and Pinto, 2000). Being adapted to simultaneous analysis of hundreds of different samples (Sato et al., 2002). each comprising variable parameters, the microchips has gained many advantages over macro-scale methods regarding efficiency and affordability (Kartalov et al., 2006). In the last decades with progressive arrival of microchip technology, a body of biochemical and biological experiments has been performed using this technology with remarkable efficacy. Several experiments which are commonly performed by these microchips are listed in Table 1 . In fact by the advent of micro-analyzing methods like HPLC in the past; several revolutionary changes in cellular and molecular biology which demanded high sensitive detectors; the advent of micro-systems and a breakthrough in micro-electronics industry; and finally the desire of human to apply low cost, portable and high-throughput systems for detection of different disorders resulted in the emerging of current high-tech microchips (Whitesides, 2006).

These appealing micro-systems firstly described in 1958 by Jack Kilby, an American electronic engineer, who in 2000 honored by Nobel Prize in physics. Primarily, the system had an elementary structure. Subsequently, more advanced micro-fluidic systems were developed in the form of gas chromatography in 1970. For almost 20 years, these novelties have not attracted many scientists. But since 1990, a wide spectrum of distinct investigations has dedicated in this field of study which revolutionized the science, especially the medical technology. (Dingwall, 1979; Smith, 1984; Holden, 1989; Zubritsky, 1999;

${ }^{1}$ Department of Clinical Biochemistry, Cellular and Molecular Research Center, 5Department of Medical laboratory sciences, Faculty of Allied Medicine, Qazvin University of Medical Sciences, Qazvin, 2Department of Hematology, Faculty of Allied Medicine, Tehran University of Medical Sciences, 3Department of Microbiology, School of Medicine, Shahid Beheshti University of Medical Science, Tehran, 4Stem cell Research Center, Department of Biochemistry, School of Medicine, Golestan University of Medical Sciences, Gorgan, Iran*For correspondence: haematologicca@gmail.com 
Table 1.Several Experiments and Methodologies which Have Been Performed in the Frame of Different Types of Microchips

\begin{tabular}{|c|c|}
\hline Reference & Technology \\
\hline (Hamilton, 1990) & Micro-chemical analyzing \\
\hline (Ekins and Chu, 1991) & Immunoassay \\
\hline (Southern et al., 1992) & Arrays of oligonucleotides \\
\hline (Fahy, 1993) & Molecular nanotechnology \\
\hline (Maier et al., 1994) & $\begin{array}{l}\text { Oligonucleotide } \\
\text { hybridization }\end{array}$ \\
\hline $\begin{array}{l}\text { (Jacobson and Ramsey, } \\
\text { 1995) }\end{array}$ & Electrophoresis \\
\hline (Tracey et al., 1995) & Cell analysis; Deformability \\
\hline (Kricka, 1998) & $\begin{array}{l}\text { Clinical automation \& } \\
\text { robotics }\end{array}$ \\
\hline (Cheng et al., 1996b) & Probe ligation; LCR \\
\hline (Parinov et al., 1996) & DNA sequencing \\
\hline $\begin{array}{l}\text { (Jacobson and Ramsey, } \\
\text { 1996) }\end{array}$ & $\begin{array}{l}\text { Probe ligation; Restriction } \\
\text { fragment analysis }\end{array}$ \\
\hline (Cheng et al., 1996a) & Molecular diagnostics \\
\hline (Li and Harrison, 1997) & Cell analysis; Isolation \\
\hline (Xue et al., 1997) & Mass spectrometry \\
\hline (Guschin et al., 1997) & DNA synthesis \\
\hline (Hadd et al., 1997) & Enzyme assay \\
\hline (Barnaby, 1997) & $\begin{array}{l}\text { detection of biological } \\
\text { warfare agents }\end{array}$ \\
\hline (Cheng et al., 1998) & $\begin{array}{l}\text { Nucleic acid amplification; } \\
\text { Multiplex PCR }\end{array}$ \\
\hline (Cheng et al., 1998) & $\begin{array}{l}\text { Nucleic acid amplification; } \\
\text { DOP-PCR }\end{array}$ \\
\hline (Ibrahim et al., 1998) & Real-time PCR \\
\hline (Schrum et al., 1999) & Flow cytometry \\
\hline (Dolnik et al., 2000) & Capillary electrophoresis \\
\hline (Schmalzing et al., 2000) & SNP detection \\
\hline $\begin{array}{l}\text { (Lockhart and Winzeler, } \\
2000)\end{array}$ & $\begin{array}{l}\text { Gene expression studies \& } \\
\text { microarray }\end{array}$ \\
\hline (Tudos et al., 2001) & point of care testing \\
\hline (Verpoorte, 2002) & forensic analysis \\
\hline (Kricka and Wilding, 2003) & PCR \\
\hline (Garcia-Egido et al., 2003) & combinatorial chemistry \\
\hline (Kartalov and Quake, 2004) & microELISA \\
\hline (de Boer et al., 2005) & $\begin{array}{l}\text { Capillary liquid } \\
\text { chromatography }\end{array}$ \\
\hline (Craighead, 2006) & single molecule analysis \\
\hline (Dittrich and Manz, 2006) & drug discovery \\
\hline (Kim et al., 2007) & $\begin{array}{l}\text { culture of adherent } \\
\text { mammalian cells }\end{array}$ \\
\hline (Nge et al., 2013) & Proteomics \\
\hline (Martinez et al., 2008) & $\begin{array}{l}\text { Laser induced fluorescence } \\
\text { (LIF) }\end{array}$ \\
\hline (van Noort et al., 2009) & Stem cell research \\
\hline (Price et al., 2009) & Nucleic acid assays \\
\hline (Granieri et al., 2010) & $\begin{array}{l}\text { protein and cell-based drug } \\
\text { screening }\end{array}$ \\
\hline (Agresti et al., 2010) & biomolecule production \\
\hline (He and Herr, 2010) & Immunoblotting \\
\hline
\end{tabular}

Table 1 (Continued). Several Experiments and Methodologies which Have Been Performed in the Frame of Different Types of Microchips

\begin{tabular}{|l|l|}
\hline \multicolumn{1}{|c|}{ Reference } & \multicolumn{1}{c|}{ Technology } \\
\hline (Wang and Bodovitz, 2010) & Metabolomics \\
\hline (Koirala et al., 2011) & DNA/microRNA profiling \\
\hline (Kumar et al., 2011) & $\begin{array}{l}\text { Hybrid Opto-Electric Ma- } \\
\text { nipulation }\end{array}$ \\
\hline (Jokerst et al., 2012) & Environmental analysis \\
\hline (Nge et al., 2013) & Space exploration \\
\hline (Sheng et al., 2012) & Electrochemical Detection \\
\hline (Olsen et al., 2013) & Cell migration analysis \\
\hline (Jarvas and Guttman, 2013) & Cell sorting \\
\hline (Luongo et al., 2013) & $\begin{array}{l}\text { Electrical impedance spec- } \\
\text { troscopy }\end{array}$ \\
\hline (Masrie et al., 2014) & $\begin{array}{l}\text { Bio-particle concentration } \\
\text { assay }\end{array}$ \\
\hline (Ohnishi et al., 2014) & $\begin{array}{l}\text { Nucleic acid sandwich } \\
\text { hybridization }\end{array}$ \\
\hline (De et al., 2014) & Epigenetic analysis \\
\hline (Zhou et al., 2014) & Monitoring cell secretion \\
\hline (Wu et al., 2015) & Somatic cell reprogramming \\
\hline (Yoon et al., 2015) & Methylation analysis \\
\hline (Ali et al., 2015) & PCR-RFLP \\
\hline (Pandya et al., 2015) & $\begin{array}{l}\text { Electro-Mechanical pheno- } \\
\text { typing }\end{array}$ \\
\hline (Rackus et al., 2015) & $\begin{array}{l}\text { Electrochemical immunoas- } \\
\text { say }\end{array}$ \\
\hline (Kao et al., 2015) & FISH \\
\hline (Hsu et al., 2015) & MeDIP \\
\hline (Guan et al., 2016) & $\begin{array}{l}\text { Electrochemiluminescence } \\
\text { detection }\end{array}$ \\
\hline (Jastrzebska et al., 2016) & $\begin{array}{l}\text { Heart-on-a-chip (stem cell } \\
\text { biology) }\end{array}$ \\
\hline
\end{tabular}

Backhouse et al., 2002)

The chips were first made primarily by crystal and silicium which then replaced but other more proper materials such as poly dimethyl silicone (PDMS) and a kind of epoxy polymer called SU-8 for enhancing the chip efficacy (Reyes et al., 2002). Particularly, in the construction of a chip, the structural components are fixed on a specialized surface in micro-scales. The surface generally has crystal, ceramic, polymers like PMDS and SU-8, stainless steel, or Teflon, in texture. The microchip materials mainly divided into 3 major categories: inorganic, polymer, and paper-based materials. Selecting the base material for a special micro-fluidic system is overshadowed by the base technology which the micro-chip is working with. Some of the most determined types of these associations are summarized in Table 2 (Marques and Fernandes, 2011).

Since in the production of microchips the components in use are tiny, it obviates the need for large manufactures. Other considerable advantages of using the micro-fluidic systems are decrease in costs and energy consumption, and also the reduction of harmful effects on the environment (Nind, 1999). It should be highlighted that another benefit 
Microchips and their Significance in Isolation of Circulating Tumor Cells and Monitoring of Cancers

Table 2. A Summarized Review of Process Variables which Can Affect the Selection of Base Material for Microchip Production

\begin{tabular}{|c|c|c|}
\hline Reference & Characteristics & $\begin{array}{l}\text { Types of materials in } \\
\text { use }\end{array}$ \\
\hline (Iliescu et al., 2012) & $\begin{array}{l}\text { Is categorized in inorganic materials. It is the first material used in } \\
\text { microchip synthesis. Having highly elastic features, it used commonly } \\
\text { to construct the structural components of microchips such as pumps } \\
\text { and valves. It is compatible with high temperature and pressure but } \\
\text { incompatible with the strong basic solutions. It has previously used in } \\
\text { microchips for PCR purposes. }\end{array}$ & Silicone \\
\hline (Shadpour et al., 2006) & $\begin{array}{l}\text { It is the second most common material used in microchips which is } \\
\text { transparent and inorganic. It is compatible with biological liquids and still } \\
\text { widely used in microchip structure. It generally has intensive resistance } \\
\text { against chemical substances while is incompatible with strong basic } \\
\text { solutions. It is also impermeable to gases. }\end{array}$ & Glass \\
\hline $\begin{array}{l}\text { (Wilson and Kolbinson, } \\
\text { 1983) }\end{array}$ & $\begin{array}{l}\text { It is categorized as inorganic and is basically has laminar structure which } \\
\text { is ammonium oxide in texture. It is highly temperature and pressure } \\
\text { resistant. The main disadvantage is high prices and shrinking after } \\
\text { intensification. It predominantly used in ELISA microchips and proteomic } \\
\text { studies. }\end{array}$ & Ceramic \\
\hline (Chen et al., 2004) & $\begin{array}{l}\text { It has inorganic and compatible with high temperature and pressure while } \\
\text { sensitive to corrosive solutions. It destroyed by these substances unless it } \\
\text { protected by special metallic covers. }\end{array}$ & Stainless steel \\
\hline (Pandian et al., 2010) & $\begin{array}{l}\text { It is inorganic and very resistant to different solvents. This approach is a } \\
\text { relatively unexploited and much about its characteristics are remained to } \\
\text { be fully described. }\end{array}$ & Teflon \\
\hline (Chen et al., 1999) & $\begin{array}{l}\text { It is organic and a member of polymer substances. Thermoplastics are also } \\
\text { cost effective, they are rapidly formed but are incompatible with organic } \\
\text { solvents, temperature, and high pressure. }\end{array}$ & Thermoplastics \\
\hline \multirow[b]{2}{*}{ (Klasner et al., 2009) } & \multirow{2}{*}{$\begin{array}{l}\text { PDMS is categorized in polymeric elastomers. Having low elasticity } \\
\text { modulus, facility in synthesis, low prices, as well as permeability to gases, } \\
\text { PMDS is extensively used as base material in various kinds of chips. }\end{array}$} & Polydimethylsiloxane \\
\hline & & (PDMS) \\
\hline \multirow[b]{2}{*}{ (Kovarik et al., 2013) } & \multirow{2}{*}{$\begin{array}{l}\text { TPE is in the polymer group. It is a hydrophobic substance, therefore is } \\
\text { able to facilitate the flow of liquids through the super narrow channels of } \\
\text { microchips. }\end{array}$} & Thermoset polyester \\
\hline & & (TPE) \\
\hline (Kovarik et al., 2013) & $\begin{array}{l}\text { Basically is vinyl benzene in texture. As it has a high biocompatibility, it is } \\
\text { an ideal polymer for cell culture purposes. }\end{array}$ & Polystyrene \\
\hline (Kovarik et al., 2013) & $\begin{array}{l}\text { It is a type of polymer consisting two main subunit as bisphenol A and } \\
\text { phosgene. Having a high resistance against temperature it has used in the } \\
\text { chips working as DNA thermal cyclers. }\end{array}$ & Polycarbonate \\
\hline (Fiorini et al., 2003) & $\begin{array}{l}\text { PMMA is a derivative of polymers which has a high biocompatibility. It } \\
\text { is impermeable to different gases and very resistant to high temperatures. } \\
\text { Plexiglas and Lucite are among the commercial products of these } \\
\text { substances which are prevalently applied in making microchips }\end{array}$ & $\begin{array}{l}\text { Poly(methyl meth- } \\
\text { acrylate) }\end{array}$ \\
\hline (Wu et al., 2012) & $\begin{array}{l}\text { Polyurethane is a polymer with an acceptable biocompatibility. It is } \\
\text { resistant to basic and acidic solutions. }\end{array}$ & Polyurethane \\
\hline (Ren et al., 2011) & $\begin{array}{l}\text { Fluoropolymers have derivatives such as fluorinated ethylene-propylene } \\
\text { (FEP) and perfluoroalkoxy polymer (PFA). They are highly resistant to } \\
\text { corrosive solutions and they have a moderate plasticity capacity. }\end{array}$ & Fluoropolymers \\
\hline (Gustafsson et al., 2008) & $\begin{array}{l}\text { COC is completely transparent and has a high plasticity capacity. It is } \\
\text { hydrophobic and is widely used in the microchips for protein purification } \\
\text { purposes. }\end{array}$ & $\begin{array}{l}\text { Cyclic-olefin copoly- } \\
\text { mer }\end{array}$ \\
\hline (Luecha et al., 2011) & $\begin{array}{l}\text { Zein is a type of polymer derived from corn protein. It is currently } \\
\text { considered as a proper replacement for petroleum-based polymers. }\end{array}$ & Zein \\
\hline $\begin{array}{l}\text { (Castano-Alvarez et al., } \\
\text { 2009) }\end{array}$ & $\begin{array}{l}\text { SU - } 8 \text { is a type of polymer with a high plasticity capacity which is } \\
\text { transparent to visible light but in the ultraviolet spectrum has orange- } \\
\text { brown color. It is an epoxy-based photoresist which is able to transform to } \\
\text { a multi-layer structure. }\end{array}$ & $\mathrm{SU}-8$ \\
\hline (Kumar et al., 2015) & $\begin{array}{l}\text { It is cellulose in structure, cheap and accessible and can simply be } \\
\text { excreted. Due to its porous structure, it provides filtration and separation } \\
\text { of materials. It has also a high level of bio-compatibility. }\end{array}$ & Paper \\
\hline
\end{tabular}


of micro-fluidic systems is that they are able to provide a system that allows the reactions to be performed with a greater efficiency. According to the diffusion rules of liquids, where the distances between the materials in an especial reaction become closer, in the other hand the amount of the components decrease into nano- or femtoliter scales, the interaction of these components reaches to their maximum levels which can eventually allow the reaction to be performed faster and more comprehensive. Furthermore, as the scales are decreased, intra-molecular and tensile forces lose their interaction, while the viscosity and inter-molecular forces become predominant (Marques and Fernandes, 2011). Performing the various reactions such as molecular labeling, refinement, isolation and monitoring of the products at the same time are among the unique characteristics of micro-fluidic systems which allow the systems to accomplish a wide spectrum of experiments with the maximum levels of accuracy and efficacy (Cibilic, 2000). Undoubtedly, working in the frame of these micro-scales also facilitates the transportation of experimental milieu which is a great advantage over the large scale environments (Nge et al., 2013). In order to produce the micro-fluidic tools in the large commercial amounts they must be primarily tested in real scales. It means that their functions must be compared with the results obtained from macro-labs hence the results can be precisely attributed to the microchip. During these analyses, variety of aspects including volumes and types of materials, characteristics of devices, final products of reactions and also wastes and pitfalls have to be studied (Nge et al., 2013). Nowadays, commercial micro-fluid systems are presented by different companies including Abbot, Agilent, Micralyne, Dolomite, Micrux, and Caliper (Whitesides, 2006).

Nowadays, advanced micro-electromechanical systems (MEMS) are incorporated into biologic detectors and play especial roles as sensors. These systems encompass electrical and mechanical components (Chuang et al., 2010). In fact, micro-analytic systems which are working in Lab-on-chips structures are chemical analogous of MEMS which are applied as proper synthetic structures for analysis of multiple processes on a microscale laboratory. For example, a classical Lab-on-chip structure may selectively separate a highly complex solution to its constituents and identify these different compounds with high accuracy. To analyze the above reactions, designing a highly advanced micro-detector

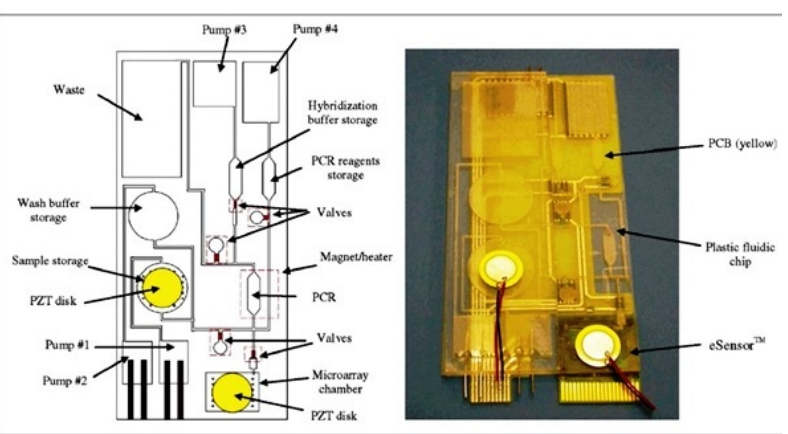

Figure 1. A Structural View of a Diagnostic Chip (Liu et al., 2004) in the structure of chips is inevitable (Nge et al., 2013). The micro-fluidic systems include ultrafine synthetic structures with a maximum capacity of several hundred femto-liters (fl) to several hundred nano-liters (nl) of samples tested and their metabolites (Guzman and Phillips, 2011). In the other word, these micro-systems measure only $1.5 \mathrm{~cm}$ to $1.5 \mathrm{~cm}$ and a thickness of approximately a few millimeters (Minhas, 2015). The overall structure consist a central core with multiple components including several micro-channels, tanks, valves, and chambers [Figure1]. Generally, tanks and micro-fluidic channels have laminar flow, a low final volume, and a high surface to volume ratio. For example, a separator channel in an electrophoresis microchip has a dimension of just $50 \mathrm{~mm}$ in wide, $15 \mathrm{~mm}$ in length and $5 \mathrm{~cm}$ in height which has a capacity of 5.37 nano-liters. Other components which optimize the performance of chips are finally added to the core. These components generally include sensors, membranes, columns, monoliths and pneumatic controls (Nge et al., 2013).

As mentioned above, it has been attempted to describe some structural details, components and performance of the microchips. However, the main purpose of this review is to discuss the importance of chips in the diagnosis and monitoring of malignancies.

\section{Key Points In The Production of A Microchip}

For the first time photolithography technology used to produce microchips. In 1998, with the advent of soft lithography technology, micro-scale modeling became accessible to scientists (Whitesides et al., 2001). In a microchip it is demanded to substantially increase the surface to volume ratio. In chip manufacturing, in order to adjust rising levels of biological communication with each other, the Self-Assembled Monolayers (SAM) is used. SAM consists of successive layers of alkane thiols, which are located on thin plates of gold. Using of these layers is a constitutive step during the production of biological micro-systems (Mrksich and Whitesides, 1996). In the microchip production several key points should be noted: the choice of materials used and the physical form of chips and components. Furthermore, the location of valves and channels should be determined on the basis of principles of engineering. In this framework, choosing various strategies depends on the final function of microchip that we expect to achieve. On the other hand, the injection of biological material in different places should be performed according to the function of the chip. This injection has to be done with pre determined purpose and fully planned. In other words, to create a pattern of targeted chemical and specific movement of any material to the designated location; design, material and internal surface properties of the channel should be such that any material would attract specifically to its target location. Soft lithography technology allows the certain chemical patterns to be designed for the chip manufacturing purposes. On the other hand, using a variety of SAMs, adhesion, humidity and other molecular properties of surfaces can be manipulated based on type and function of the chip. These properties can be changed according 
to a desirable profile (Brivio et al., 2006).

\section{Fundamental Functions in a Chip}

Fundamental functions are the major operations in micro-fluid systems which ultimately give the chip this ability to conduct targeted testing and favorable analysis in order to provide reliable results. These functions include sample preparation, separation of materials, tracking, and transitions of fluids (Nge et al., 2013). To facilitate the better understanding of the content, brief details of the actions are shown in Table 3. In fact, the final purpose of Lab-on-chip systems is the integration of all the laboratory processes on a micro-system where sample preparation, biochemical reactions, separation, detection, and ultimately accurate data analysis can be done (Wu et al., 2010). Despite all the recent scientific developments in relation to the microchips, the inclusion of all laboratory steps on a single micro unit system is not simply possible and faced with various difficulties (Sin

Table 3. Functions that Should be Included in a Diagnostic Microchip, as Well as Components and Common Techniques Used in Every Stage

\begin{tabular}{|c|c|c|c|}
\hline Critical actions & $\begin{array}{l}\text { Procedures or } \\
\text { methods }\end{array}$ & Description & Reference \\
\hline \multirow{3}{*}{ Sample preparation } & $\begin{array}{l}\text { Extraction and } \\
\text { purification }\end{array}$ & $\begin{array}{l}\text { This is a part of sample preparation before performing the main } \\
\text { test. A preferred method of choice for this purpose is Solid } \\
\text { Phase Extraction (SPE). In the majority of microchips, a kind of } \\
\text { SPE system called reversed-phase SPE columns is used. In this } \\
\text { technology the mostly used columns are silica-based. In this case, } \\
\text { the extraction is performed based on affinity with high specificity. }\end{array}$ & (Wen et al., 2008) \\
\hline & Pre-concentration & $\begin{array}{l}\text { By this method, samples with small amounts can be used } \\
\text { efficiently and the results will be more accurate. One of the most } \\
\text { common technologies at this stage is Isotachophoresis (ITP). Two } \\
\text { other techniques which are used here are temperature gradient } \\
\text { focusing and sweeping. }\end{array}$ & $\begin{array}{l}\text { (Bercovici et al., } \\
\text { 2011) }\end{array}$ \\
\hline & On-chip labeling & $\begin{array}{l}\text { The labeling is generally performed either on samples in use (Off- } \\
\text { chip) and also on certain parts of the microchip (On-chip). Micro- } \\
\text { chip labeling is accomplished with two main types: Pre-column } \\
\text { and Post-column }\end{array}$ & $\begin{array}{c}\text { (Sieben and } \\
\text { Backhouse, 2005) }\end{array}$ \\
\hline \multirow{3}{*}{ Separation methods } & Chromatography & $\begin{array}{l}\text { This is a sensitive and reliable method. In this step the liquid chro- } \\
\text { matography- and HPLC- based methods are used. }\end{array}$ & $\begin{array}{l}\text { (Taylor et al., } \\
\text { 2010) }\end{array}$ \\
\hline & Electrophoresis & $\begin{array}{l}\text { This is an efficient liquid-based separation method. Notable } \\
\text { benefits of this technique are high efficiency, high speed and } \\
\text { consumption of very small amounts of sample. In some chips } \\
\text { for better separation, a combination of this methods and } \\
\text { chromatography is applied (electrochromatography). Other } \\
\text { techniques that are used here are Isoelectric focusing and Micellar } \\
\text { electrokinetic chromatography. }\end{array}$ & $\begin{array}{l}\text { (Yang and } \\
\text { Woolley, 2010) }\end{array}$ \\
\hline & Fractionation & $\begin{array}{l}\text { One technique that works for separation based on this method is } \\
\text { Digital isoelectric fractionation. This technique uses membranes } \\
\text { with distinct specific PH dedicated to separate analytes based on } \\
\text { their isoelectric points. It is largely used in the chips dedicated } \\
\text { for detection of glycoprotein onco-markers in biological samples. } \\
\text { Another technique in use in this step is Field-flow-fractionation. }\end{array}$ & (Mai et al., 2012) \\
\hline \multirow{3}{*}{ Detection methods } & Optical detection & $\begin{array}{l}\text { These types of high precision methods are divided into two sub- } \\
\text { groups: 1- label-based methods such as fluorescence, 2- label- } \\
\text { free methods such as chemiluminescence. Fluorescence methods } \\
\text { compared with the second group have a higher sensitivity. } \\
\text { The most common optical method which is used for detection } \\
\text { purposes in microchips is Laser-induced fluorescence. In } \\
\text { contrast, UV absorbance is a labeling-free method which is also } \\
\text { commonly used in HPLC and electrophoresis systems. }\end{array}$ & $\begin{array}{l}\text { (Myers and Lee, } \\
\text { 2008) }\end{array}$ \\
\hline & $\begin{array}{l}\text { Electrochemical } \\
\text { detection }\end{array}$ & $\begin{array}{l}\text { They are as sensitive as macro-scale electrochemical detectors. } \\
\text { Today, Conductivity, amperometry and potentiometry are the } \\
\text { most common technologies in conjunction with this method, } \\
\text { used in microchips. }\end{array}$ & $\begin{array}{l}\text { (Holcomb et al., } \\
\text { 2009) }\end{array}$ \\
\hline & $\begin{array}{l}\text { Mass } \\
\text { spectrometry } \\
\text { (MS) }\end{array}$ & $\begin{array}{l}\text { MS is capable to convert tiny differences into data based on } \\
\text { mass differences and then record these data. Two ionization } \\
\text { technologies associated with this method, which are used in a } \\
\text { group of microchips include: (ESI-MS) and matrix-assisted laser } \\
\text { desorption / ionization (MALDI-MS). The former is used more } \\
\text { common in microchips. }\end{array}$ & (Kleparnik, 2013) \\
\hline
\end{tabular}


Table 3. Functions that Should be Included in a Diagnostic Microchip, as Well as Components and Common Techniques Used in Every Stage (Continued)

\begin{tabular}{|c|c|c|c|}
\hline Critical actions & $\begin{array}{c}\text { Procedures or } \\
\text { methods }\end{array}$ & Description & Reference \\
\hline \multirow{3}{*}{ Fluid manipulation } & Pumps & $\begin{array}{l}\text { Hydraulic fluid is a vital function in microchips which accelerates } \\
\text { the solution. The main types of pumps used in different microchips } \\
\text { based on their functions are divided into two categories: Passive } \\
\text { and Active. Sub-group Non-Mechanical Capillary belongs to the } \\
\text { type of Passive. Active category has different sub-groups which } \\
\text { are as follows: Electro-osmotic, Electrochemical, Pneumatic } \\
\text { peristaltic, Electro-hydrodynamic, Acoustic and Magneto- } \\
\text { hydrodynamic. }\end{array}$ & $\begin{array}{l}\text { (Lai and Folch, } \\
\text { 2011) }\end{array}$ \\
\hline & Valves & $\begin{array}{l}\text { The most common material used to produce micro-fluid valves } \\
\text { is PDMS. Having the ability to control the flow rate as well as } \\
\text { their especial direction, valves are playing important roles in } \\
\text { microchips. Valves are divided into two categories: Passive and } \\
\text { Active. Passive types include the following groups: Check valve } \\
\text { (mechanical) and Capillary burst valve (non-mechanical) and } \\
\text { active includes the following groups: Pneumatic (mechanical) } \\
\text { and Phase-change (non-mechanical) and Magnetic (mechanical). }\end{array}$ & $\begin{array}{c}\text { (Kim et al., } \\
\text { 2012a) }\end{array}$ \\
\hline & Mixing & $\begin{array}{l}\text { Laminar flow of materials in small quantities together with } \\
\text { super narrow networks of chip channels help perfectly mixing } \\
\text { of materials together. The methods in use are divided into two } \\
\text { categories: Active and Passive. Active types are Electro-kinetic, } \\
\text { Acoustic and Magneto-hydrodynamic. Passive types include T- } \\
\text { or Y-mixers, Lamination and Chaotic advection. }\end{array}$ & (Lee et al., 2011) \\
\hline
\end{tabular}

et al., 2011). Technologies such as Fluidic interconnects (Mair et al., 2006), Micro-dialysis (Nandi and Lunte, 2009), and Droplet micro-fluidics (Seemann et al., 2012) are among the methods which are currently used for optimum integration of processes performed on a chip.

\section{Cancer and the Challenges Ahead}

Cancer or malignancy is defined as the indiscriminate and uncontrolled proliferation of normal cells in the body. Currently, cancer is one of the most complex disorders that plague the human being and is one of the main causes of death around the world. In other words, according to published statistics, in developed and under-developed countries cancer is the second and third cause of death, respectively. Although in the last decades remarkable breakthroughs have been made, and diagnosis and monitoring of various malignancies are performing accurately, but many aspects of this challenging disorder remain to be fully clarified. Failure of many theories and techniques in screening and early diagnosis of cancer, lack of full understanding of the pathogenesis of cancers, imperfect and unreliable remedies, tolerance of tumor cells against current modalities, frequent relapses after remission phase, heterogenic chromosomal abnormalities, plasticity of malignant cells and finally tumor metastasis are among the most important challenges in dealing with cancer (Azad et al., 2015).

In most cases, cancer originates from one or multiple chromosomal abnormalities, which can lead to a clonal disorder, changes in gene expression profiles, cell cycle and apoptosis deregulation and eventually the cell will undergo uncontrollable proliferation. Genetic abnormalities which lead to malignancy primarily occur in key elements of intracellular signaling, proto-oncogenes and tumor suppressor genes. Since 2004, abundance of investigation efforts has been accomplished to precisely identify the biology of cancers, which has accelerated the prevention, diagnosis, and treatment strategies of these disorders (Alexis et al., 2008). Obviously, there is a long elapse between initiation of chromosomal disorders and cancer formation in the body. As a result, if the cancer would be detectable prior to complete formation of tumor bulk, its management would be easier and the treatment might be more successful (Seigneuric et al., 2010).

Certainly, in each stage of a tumor an ideal sampling can strongly affects the diagnosis and treatment strategies. Therefore, the sampling is always one of the most important challenges regarding the cancer diagnosis (Mach et al., 2013). Traditional sampling methods such as collecting the biopsy from suspicious tissues are quite invasive and painful which harm the patient's body. As a result, preparing a proper and sufficient sample is not always easily made. Having these obstacles, it has been tried to make the cancer diagnosis feasible using body fluids especially blood, urine, and saliva which are more accessible with the minimum risk. One of these methodologies is to detect the cancer associated circulatory biomarkers in these fluids which can be considered as markers for prevention, prognosis, diagnosis and monitoring of cancers (Fabian et al., 2008). Biomolecules including DNA, mRNA, micro-RNA, proteins, lipids, exosomes, and the most important, circulatory tumor cells (CTCs) are among the most common biomarkers used for this purpose. According to previous studies, in addition to the affected tissues, tumor cells are also detectable in body fluids especially blood in which 1-10 malignant cells $/ \mathrm{ml}$ are identifiable in patients with solid tumors. More precisely, prior to metastatic phase, 1 CTC per 108 mononuclear cells can be detected in blood 
which is promoted to 1 CTC per 105 mononuclear cells in metastatic phase. Conclusively, by using cancer associated biomarkers in blood and other body fluids the difficulties of traditional sampling have been obviated. This strategy is a fundamental step in screening and diagnosis of various types of cancer (den Toonder, 2011).

\section{Single Cell Isolation}

Nowadays, cell analysis techniques play important roles in designing the various drugs, tissue engineering, development of different cell lines, understanding the intracellular signaling, and stem cell \& cancer research. This process is required efficient isolation and cultivation of the cells. One of the main challenges encounter with the cell isolation is the heterogeneous nature of target cells which highlights the needs for the development of single cell isolation and analysis techniques (Van Loo and Voet, 2014). With the respective of frequency, the most applicable technologies which currently used for single cell isolation purposes are flow cytometry (33\%), manual cell picking $(17 \%)$, laser micro-dissection $(17 \%)$, random seeding/dilution (15\%), and microchips (12\%) (Gross et al., 2015). Among these, laser-directed micro-dissection is a strong method for the collection of malignant cells in solid tumors (Emmert-Buck et al., 1996).

In some cases, the microchip technology is preferred for the cell isolation. For instance, when the cell analysis of a tumor bulk demands a high accuracy and sensitivity or in the cases where differentiation of viable and non-viable cells is required, using a microchip is almost inevitable (Zhao et al., 2013). The microchips which currently used specifically for single cell isolation generally work based on three main principles: Droplet-in-oil-based isolation (Brouzes et al., 2009), Hydrodynamic cell traps (Di Carlo et al., 2006), and Pneumatic membrane valving (GomezSjoberg et al., 2007). Sensitivity of basic method used in chip for single cell isolation, quality and yield of isolated cells, and the compatibility of isolation method with analysis hardware are among the top concerns regarding the use of microchips for cell isolation (Nagrath et al., 2007). In the recent years, single cell isolation as a field of novel applied research has several subcategories. One of these subcategories is the isolation and purification of circulating tumor cells (CTCs) from blood as a noninvasive sampling which is efficient for monitoring of cancer (Gross et al., 2015).

\section{Isolation and Purification of CTCs using Microchip Technology}

Obtaining useful information related to cancer pathogenesis and its monitoring requires isolation and purification of cancer cells from affected tissues, blood or other body fluids. Indeed, collection of circulatory tumor cells and conducting the complementary experiments on the samples using rapid and non-invasive methods provides a unique chance for clinicians to initiate the treatment procedures in early stages prior to fatal metastatic phase. CTCs are often accumulated in peripheral blood before full development of metastatic phase. It is clear that the detection and isolation of these cells can be performed more conveniently in this phase. In this stage, CTCs acquire secondary genetic abnormalities which are pre-requisite for a successful metastasis and formation of a new tumor originated from the primary tumor (Maheswaran and Haber, 2010). An ideal method for isolation of CTCs should be in consistent with the following criteria: high specificity and sensitivity, sample enrichment, and statistical consideration (Allan and Keeney, 2010).

CTC isolation process is generally performed via various methods including: PCR-based approaches, Flow cytometry, Laser scanning cytometry, CellSearch (Veridex), EPISPOT, and microchip technology (Gross et al., 2015). Among these approaches, microchip technology along with EPISPOT and Veridex with the ability to detect one tumor cell among 107 peripheral blood mononuclear cells (PBMCs) is categorized as the most efficient and sensitive method for CTC isolation purposes. This technique is also the selective method where a large amount of pure cells is needed. Moreover, this technology is a powerful quantitative method which is able to differentiate the viable from non-viable cells and allows the distinct analysis of each group (Nagrath et al., 2007).

Undoubtedly, because of extremely low counts, CTCs demand highly sensitive methods to be isolated. To achieve this, one strategy is to use surface CD-markers to differentiate tumor cells from normal blood cells. For example, surface marker CD45 as a specific marker for non-tumor cells can be used to efficiently isolate the majority of tumor cells. However, using tumor specific CD-markers are associated with multiple challenges. One of these challenges is the variability of tumor cell immuno-phenotype during different phases of cancer (progression, metastatic, etc.) which makes the isolation of CTCs very complicated or in some cases, even impossible (Goodale et al., 2009). Furthermore, some tumor cells during the migration to the secondary tissue undergo a process so called epithelial-to-mesenchymal transition (EMT). During this process migration and metastasis potential of tumor is promoted, the cell-cell adhesion property is reduced, epithelial markers are decreased and mesenchymal markers are expressed, and even the cell morphology undergoes several alterations (Yang and Weinberg, 2008). As a result, discovering novel tumor specific biomarkers which are stable during different phases of cancer progression can propose the more sensitive strategies to isolate the CTCs. Stable tumor specific biomarkers are divided into two main categories: tumor type-specific markers, and epithelial-specific markers. In the first class, PSA, CEA, and MammoglobinHER2neu-Mucin1 are the typical hallmarks for prostate, colorectal, and breast cancer, respectively (Xi et al., 2007). The most prominent tumor markers in the second class are EpCAM, also known as ESA, CD326, HEA125, or TACSTD1 and the various cytokines (Pantel et al., 2008).

One further challenge regarding the cancer monitoring is the isolation of CTCs in early-stage cancerous patients. In this case, prognostic markers which are expressed adequately in early stages should be considered as proper 
target for detection (Allan and Keeney, 2010). The most applicable markers in this regard include cytokeratin-19, cytokeratin-20 or CEA, and PSA or PSCA which are used to isolate CTCs in early stages of breast, colorectal, and prostate cancers, respectively (Stathopoulou et al., 2003; Allen-Mersh et al., 2007; Helo et al., 2009).

New approaches propose the expression measurement of genes encoding for biomarkers in the molecular levels. In this regard the following measurements can be mentioned: assessment of HER-2 gene amplification to determine the severity of breast cancer (Meng et al., 2004), uPAR and HER-2 gene expression profile to monitor the breast cancer (Meng et al., 2006), insulinlike growth factor-I receptor gene expression to ample purification of tumor cells (de Bono et al., 2007), detection of EGFR gene mutation to efficiently isolate the CTCs of lung cancer (Maheswaran et al., 2008), and EGFR gene expression profiling to isolate the CTCs of breast cancer after metastatic phase (Payne et al., 2009).

One of the other challenges regarding the CTC isolation is associated with difficulties in sample enrichment. Enrichment approaches are generally based on one of two mechanisms of positive selection and negative selection. These mechanisms in turn use three main methods for Sample Enrichment: 1: immuno-magnetic methods, 2: density gradient centrifugation, and 3: cell size restrictive filtration (Allan and Keeney, 2010). Taken together, using microchips due to high efficiency, acceptable precision and sensitivity, and affordable prices is one of the most ideal methods for effective isolation of CTCs from blood. In the following sections multiple CTC isolation methods using microchips are described.

\section{Microchip Mediated CTC Isolation Using Size-Based Technology}

Microchips designed based on this technology differentiate the CTCs from normal blood cells regarding their different sizes (Kim et al., 2015). As an advantage, in this method the needs for specific biomarkers are obviated, while tumor cell size heterogeneity is considered a challenging feature which can fail the purification of small size tumor cells. However, in this technology using $8-11 \mu \mathrm{m}$ diameter micro-cavities or $5-7 \mu \mathrm{m}$ wide slots allows the efficient isolation of tumor cells of various sizes (Hosokawa et al., 2010).

Alternatively, in some cases the flow profile of cells which is based on inertial migration is applied to separate the tumor cells with huge sizes (Bhagat et al., 2011). In this regard, dielectrophoretic force with a higher accuracy and sensitivity may also used to isolate the cells (Moon et al., 2011). One of the primary studies in this case has been made in 2000 in which Dielectrophoretic Field-Flow Fractionation (DEP-FFF) was used to selectively isolate the different types of blood cells (Yang et al., 2000).

In 2007 and 2011 Zheng et al. have succeeded to isolate the CTCs using a microchip with specialized micro-filter membrane which is able to sensitively discriminate the tumor cells based on their different sizes (Zheng et al., 2007; Zheng et al., 2011). Similarly, in another study particular chips so called "filtration chips" with a spiral channel and two filters were used for purification of breast cancer cells from the blood with remarkable efficiency (Kuo et al., 2010). In 2011, tumor cells were isolated with an excellent efficiency (96\% yields) from diluted blood. In this study the special chips were used in which cell morphology was also added to the isolation criteria further than the cell size. These microchips take advantage of a distinct technology referred to as "deformabilitybased analysis" (Hur et al., 2011). Another favorable result was taken in the same year using dielectrophoretic features as an alternative strategy to isolate the CTCs from blood samples (Moon et al., 2011). In 2012, Lim EJ et al have been elected to use a method called "particle trajectory analysis" in order to isolate the prostate cancer cells. Microchips using this technology are categorized as "particle focusing chips" which use the cell size characteristics for the isolation purposes (Seigneuric et al., 2010).

\section{Microchip Mediated CTC Isolation Using Immunoaffinity-Based Technology}

In this technology, the isolation is conducted using one of the tumor specific markers. The antibodies play an integral role in Immunoaffinity-based CTC isolation methods. They specifically identify the target tumor markers that eventually form an Ag-Ab complex which can be targeted to isolate the CTCs in the sample (Zhang and Nagrath, 2013).

In 1970s a surface antigen called Epithelial Cell Adhesion Molecule (EpCAM) was identified to be highly expressed on the surface of the cells in several tumors including colon, prostate, lung, kidney, breast, and ovarian cancers. In 2004, EpCAM was selected as a proper target for monoclonal antibodies in order to isolate the CTCs in blood samples using Veridex which is a macro-scale method (Zhang and Nagrath, 2013). This antigen is a biomarker which is also extensively used as a target for CTC isolation in micro-scale methods such as Immunoaffinity-based chip technology (Nagrath et al., 2007). As a disadvantage, this method is not a proper choice where the viable cells are needed. In these cases sized-based or dielectrophoretic-based methods are preferable. This limitation is strongly attributed to vulnerability of the viable cells to some steps of the procedure such as washing of antibodies which are bound to surface antigens with a high affinity. In addition, the target cells might also be contaminated with unwanted cells due to the unspecific binding of the antibodies (Zhang and Nagrath, 2013). Obviously, the slight amount of tumor cells through a multitude of normal blood cells augments the complexity of problem which leads to unreliable analysis.

In 2009, a new approach of CTC isolation was developed as "aptamer selection chip" which possesses a strong ability of isolation based on immunoaffinity technology (Dharmasiri et al., 2009). In the following year, "Herringbone-chips" which are PDMS in texture were described with a high ability to isolate CTCs of prostate cancer in blood samples (Stott et al., 2010). Subsequently, geometrically enhanced differential immunocapture 
(GEDI) chips were used to collect the CTCs of this type of cancer (Gleghorn et al., 2010). In another study in 2010, simultaneous use of E-selectin and EpCAM antigens was discussed to have a higher specificity for isolation of CTCs. The mechanism behind was the fact that combined use of the two antigens enhances the marginalization of CTCs on blood vessels, a process which facilitates the CTC isolation. This micro-fluidic system is referred to as "E-selectin biomimetic chip" (Myung et al., 2010). A study in 2011, in order to detect the KRAS gene mutation in colorectal cancer, used a special sort of chips named "Integrated CTC selection chips" with a remarkable capacity for tumor cell isolation (Dharmasiri et al., 2011). Later in 2013, NCI-1650 antigen was applied as an immunologic target with a nitrocellulose membrane as scaffold to isolate the CTCs of lung cancer (Zhang et al., 2013). In the same year Zhao et al. designed a system called "NanoVelcro Chip" coupled with ArcturusXT" laser capture microdissection (LCM) technology to isolate the CTCs of prostate cancer for the next generation sequencing [NGS] purposes (Zhao et al., 2013). In 2014, a modern microchip named "geometrically enhanced mixing (GEM) chip" was successfully used to isolate the pancreatic cancer CTCs with a great specificity and accuracy (Sheng et al., 2014). At the same time a new generation of microchips adopted simultaneous use of EpCAM and Caveolin-1 antigens to isolate the CTCs through a heterogeneous population of cells in breast cancer patients (Kim et al., 2014).

\section{Microchip Mediated CTC Isolation using Immunomagnetic-Based Technology}

The only FDA approved method for tumor cell or stem cell purification from fluids such as blood is a macroscale technology (Veridex) which uses immunomagnetic labeling to capture the target cells. Currently, new generation of chips in micro-scales have been developed which are able to collect the magnetically-labeled CTCs from blood samples (Chen et al., 2011b). In 2009, a sort of chip called "Magsweeper chip" with immunomagnetic separation technology was applied to isolate the breast cancer cells from whole blood (Moon et al., 2011). In 2010, a different type of this category called "selfassembled magnetic chip" introduced for high efficient isolation of B lymphocytes from blood samples of leukemia and lymphoma patients (Saliba et al., 2010). Along with these studies, in 2011 a special group of chips referred to as "negative selection chips" were used to isolate breast cancer cells from PBMCs, however this group was associated with a moderate efficiency $(60 \%$ yields) (Chen et al., 2011a). The combined micro-magnetic micro-fluidic device as a novel chip system was developed in 2012 to purify the tumor cells but the efficiency did not overtake the former method (Kang et al., 2012).

\section{Detailed Investigation of Cancer Biology Using Microchip Technology}

In the recent years a body of various methods has been applied for diagnosis, monitoring, as well as studying the underlying mechanisms of cancer. All the previously described approaches have their own advantages and disadvantages. They have also associated with heterogeneous degrees of accuracy and sensitivity. In a quick glance, currently available cancer diagnosis and monitoring techniques include pathologic examination, various PCR analysis, blotting techniques, DNA microarray, tissue microarray, flow cytometry and immunophenotyping, immuno-histochemistry, cytogenetic studies, FISH, and genome sequencing. Among this diverse range of approaches, DNA microarray is one of the most applicable and efficient strategies for extensive screening of tumors. This technology is also known as Gene array, Chips, and Biochips and should not be confused with tissue microarray (Aitman, 2001). This system generally exerts its role in understanding of the biology behind the diseases in the frame of three main forms: gene expression profiling, DNA sequencing, and genotyping (Fey, 2002).

A comprehensive bulk of information on biology and pathogenesis of different types of human cancers can be deciphered using DNA and RNA molecules of tumor cells extracted from blood and other clinical samples including saliva, urine, sputum, stool, and bronchial lavage materials (Zhang and Nagrath, 2013). Moreover, using large spectrum of other macromolecules such as various ranges of proteins, hormones, lipid molecules, micro-RNAs, as well as serum micro-vesicles contributes to a better understanding of basic mechanisms of diseases and finding the novel diagnostic and treatment strategies (Zhang and Nagrath, 2013).

miRNAs constitute approximately $1 \%$ of human genes and they are encoded as mono- and poly-cistronic genes. The genes encoding these small non-coding RNAs are located either independently or between other protein-coding regions. The most segments of the genome responsible for miRNA coding are not dedicated for other specific genes. MiRNA specific arias include fragile regions on human chromosomes and expressed independently of the others genes. RNA polymerases I and II transcribe the miRNA genes into primary miRNA transcripts. MiRNAs have been discovered to be largely involved in several metabolic and pathologic processes including tissue formation, cell proliferation and death, lipid metabolism, stem cell differentiation, as well as cancer formation and progression. Regarding these diverse functions, the roles of miRNAs in vertebrates are comparable with transcription factors (Wang et al., 2016). Furthermore, circulatory miRNAs are stable elements which currently are considered as highly valuable biomarkers for diagnosis and monitoring of human cancers (Tsujiura et al., 2010).

Additional potential biomarkers used for cancer diagnosis and monitoring are micro-vesicles or exosomes. However, exosome-based cancer diagnostics requires techniques enabling the differential identification of exosomes from extremely similar elements in blood samples (Ratajczak et al., 2006). Exosomes are protective structures encircling a group of proteins, lipids, and miRNAs. The resulting structures have a size of 60$100 \mathrm{~nm}$, which exist both as intracellular and circulating 
Table 4. A List of the Most Important Exploitations and Studies in the Field of the Biology, Diagnosis, Treatment, and Monitoring of the Cancer Using Microchip Technology

\begin{tabular}{|c|c|c|c|}
\hline Reference & Results & Study description & $\begin{array}{l}\text { Techniques used in } \\
\text { the frame of chip } \\
\text { technology }\end{array}$ \\
\hline (Wang et al., 2015b) & $\begin{array}{l}\text { No false positive result in negative control } \\
\text { group or false negative result in patient } \\
\text { group was detected. It was even detected } \\
\text { a JAK2 positive patient which was missed } \\
\text { before by other methods. }\end{array}$ & $\begin{array}{l}\text { Chip-based screening of Jak2 } \\
\text { V617F point mutation for } \\
\text { diagnosis of lymphoproliferative } \\
\text { disorders especially polycytemia } \\
\text { vera. }\end{array}$ & $\begin{array}{l}\text { DNA extraction } \\
\& \text { amplification \& } \\
\text { mutation analysis }\end{array}$ \\
\hline $\begin{array}{l}\text { (Ying-Yan et al., } \\
\text { 2008) }\end{array}$ & $\begin{array}{l}\text { GRP78 is a chaperone responsible for } \\
\text { chemotherapy resistance is some cancer } \\
\text { types. GRP78 in A23187 induced cells was } \\
\text { over-expressed and after VP-16 exposure the } \\
\text { apoptosis rate significantly diminished. It } \\
\text { was concluded that GRP78 plays an integral } \\
\text { role In cell lines resistance to chemotherapy. }\end{array}$ & $\begin{array}{l}\text { NCI-H460 cell line representing } \\
\text { the lung cancer was cultured on } \\
\text { PMDS microchips in the presence } \\
\text { and absence of A23187. Then the } \\
\text { GRP78 expression was measured } \\
\text { in both mRNA and protein levels. } \\
\text { Ultimately, cell apoptosis assay } \\
\text { was performed after VP-16 (a } \\
\text { chemotherapy drug) exposure. }\end{array}$ & $\begin{array}{l}\text { Cell culture, } \\
\text { Immunofluorescence } \\
\text { \& Electrophoresis }\end{array}$ \\
\hline (Munro et al., 1999) & $\begin{array}{l}\text { Time required for testing in slab-gel } \\
\text { was about two and a half hours and in } \\
\text { conventional CE microchip about } 15 \\
\text { minutes. This time with greater efficiency, } \\
\text { reduced to less than three minutes in chip } \\
\text { systems. }\end{array}$ & $\begin{array}{l}\text { Optimization of } r \text { molecular } \\
\text { diagnosis of B, and } \mathrm{T} \\
\text { lymphoproliferative disorders } \\
\text { in slab gel electrophoresis, } \\
\text { conventional CE, and micro- } \\
\text { fluidic systems. }\end{array}$ & Electrophoresis \\
\hline (Tian et al., 2000a) & $\begin{array}{l}\text { By using chip, the time required to perform } \\
\text { single-strand conformation polymorphism } \\
\text { analysis and the type and structure } \\
\text { optimization fell to about two minutes and } \\
\text { the efficiency promoted to more than a } \\
\text { hundred-fold. }\end{array}$ & $\begin{array}{l}\text { Detection optimization of the } \\
\text { genomic aberrations such as } \\
\text { mutations, deletion etc. in the } \\
\text { genes including BRCA1 and } \\
\text { BRCA2 using hetero-duplex } \\
\text { analysis and allele-specific } \\
\text { DNA amplification techniques } \\
\text { or a combination of these two } \\
\text { techniques in CE chips. }\end{array}$ & $\begin{array}{l}\text { combining allele- } \\
\text { specific DNA } \\
\text { amplification } \\
\text { with heteroduplex } \\
\text { analysis by capillary } \\
\text { electrophoresis chip }\end{array}$ \\
\hline $\begin{array}{l}\text { (Schrauder et al., } \\
\text { 2012) }\end{array}$ & $\begin{array}{l}46 \text { miRNAs were detected to be down- } \\
\text { regulated and } 13 \text { miRNAs had significant } \\
\text { increase in expression levels. MiR-202, due } \\
\text { to its remarkable decrease was considered as } \\
\text { a significant preventive element of the breast } \\
\text { cancer formation. }\end{array}$ & $\begin{array}{l}\text { MiRNAs profiling in early stages } \\
\text { of breast cancer patients on } \\
\text { especial chips. }\end{array}$ & $\begin{array}{l}\text { Array-based miRNA } \\
\text { profiling }\end{array}$ \\
\hline (Sato et al., 2001) & $\begin{array}{l}\text { Using chips in this study resulted in the } \\
\text { reduction of CEA detection time from } 45 \\
\text { hours to } 35 \text { minutes. Additionally, the sensi- } \\
\text { tivity and reproducibility of the method was } \\
\text { significantly increased compared to macro- } \\
\text { scales techniques. }\end{array}$ & $\begin{array}{l}\text { Tracing of carcino-embryonic } \\
\text { antigen in human saliva using } \\
\text { three different antibodies based } \\
\text { on chip technology for diagnosis } \\
\text { of colon cancer. }\end{array}$ & $\begin{array}{l}\text { Sandwich } \\
\text { immuoassay }\end{array}$ \\
\hline (Chaw et al., 2007) & $\begin{array}{l}\text { Cancer cells, intelligently migrated toward } \\
\text { the center of channels with complete culture } \\
\text { medium. In this study, the cell membrane } \\
\text { was introduced as a therapeutic target in } \\
\text { controlling the cancer metastasis. }\end{array}$ & $\begin{array}{l}\text { Study of metastatic and } \\
\text { deformation pattern of cancer } \\
\text { cells using cell culture on the } \\
\text { margins of microchip channels in } \\
\text { the serum deficient medium. }\end{array}$ & $\begin{array}{l}\text { co-culture for } \\
\text { studying cancer } \\
\text { metastasis }\end{array}$ \\
\hline $\begin{array}{l}\text { (Cantafora et al., } \\
\text { 2003) }\end{array}$ & $\begin{array}{l}\text { Cholesterol was proposed as a positive } \\
\text { inductor of the factors such as LXR-alpha } \\
\text { and FXR. }\end{array}$ & $\begin{array}{l}\text { Study of RNA messengers that } \\
\text { involved in lipid trafficking } \\
\text { of human intestinal cells. The } \\
\text { technology used in this study } \\
\text { include: RT-PCR with competimer } \\
\text { technology and microchip CE }\end{array}$ & $\begin{array}{l}\text { reverse-transcription } \\
\text { polymerase chain } \\
\text { reaction }\end{array}$ \\
\hline
\end{tabular}

in blood (Taylor and Gercel-Taylor, 2005).

Nowadays, highly advanced micro-fluidic systems have been introduced to detect all the above mentioned biomarkers in blood samples and other body fluids. These micro-scale systems have increasingly attracted many cancer investigation and clinical centers to use them as proper alternative methods rather than high price macroscale strategies (Hung et al., 2013). Using slight amounts of samples with remarkably sensitive, accurate, high throughput, and reproducible results allows microchips to be extensively used for tumor diagnosis and monitoring (Pappalardo et al., 1998). 
Table 4. A List of the Most Important Exploitations and Studies in the Field of the Biology, Diagnosis, Treatment, and Monitoring of the Cancer Using Microchip Technology (Continued)

\begin{tabular}{|c|c|c|c|}
\hline (Yung et al., 2009) & $\begin{array}{l}\text { EGFR related to exon- } 19 \text { deletion and } \\
\text { L858R mutation were reported in } 17 \% \text { and } \\
26 \% \text { plasma samples, respectively. Plasma } \\
\text { concentrations of mutant sequences were } \\
\text { shown to have a significant reduction in } \\
\text { patients with remission. }\end{array}$ & $\begin{array}{l}\text { Detection of two common types } \\
\text { of EGFR (in-frame deletion in } \\
\text { exon-19 and L858R at exon-21) } \\
\text { in plasma and tissue samples } \\
\text { of patients with lung cancer } \\
\text { using micro-fluidic systems and } \\
\text { quantitative confirmation of these } \\
\text { two disorders in patient's samples. }\end{array}$ & Digital PCR platform \\
\hline (Song et al., 2009) & $\begin{array}{l}\text { The pattern of implantation of tumor cells is } \\
\text { fully targeted and is associated with the organ } \\
\text { microenvironment. Microenvironment of } \\
\text { organs was considered as therapeutic targets } \\
\text { in cancer control. }\end{array}$ & $\begin{array}{l}\text { The effects of simulated vascular } \\
\text { system and chemokines CXCL- } \\
12 \text { on development and grading } \\
\text { determination of cancer cells on a } \\
\text { microchip. }\end{array}$ & $\begin{array}{l}\text { co-culture for } \\
\text { studying tumor } \\
\text { microenvironment }\end{array}$ \\
\hline $\begin{array}{l}\text { (Mitchell et al., } \\
\text { 2008) }\end{array}$ & $\begin{array}{l}\text { MiR-141 in these patients was significantly } \\
\text { overexpressed and could be considered as an } \\
\text { important biomarker. }\end{array}$ & $\begin{array}{l}\text { Application of microchips to } \\
\text { determine the profile of micro- } \\
\text { RNAs in prostate cancer (serum } \\
\text { samples). }\end{array}$ & $\begin{array}{l}\text { TaqMan miRNA } \\
\text { qRTPCR array }\end{array}$ \\
\hline (Huang et al., 2009) & $\begin{array}{l}\text { A week after the co-culture, the macrophages } \\
\text { have invaded against the breast cancer } \\
\text { cells. Profiling of stromal cells in the } \\
\text { microenvironment of metastatic cancers } \\
\text { can be used as therapeutic targets in cancer } \\
\text { control. }\end{array}$ & $\begin{array}{l}\text { The effects of stromal cells on } \\
\text { biology of metastatic breast } \\
\text { cancer cells during co-culture } \\
\text { of these cells together on the } \\
\text { hydrogels designed in chips. }\end{array}$ & $\begin{array}{l}\text { 3D-culture for } \\
\text { studying interactions } \\
\text { between tumor and } \\
\text { stromal cells }\end{array}$ \\
\hline (Pekin et al., 2011) & $\begin{array}{l}6 \text { new mutations in the KRAS genes } \\
\text { have been reported. In this study, the } \\
\text { determination of exact quantity of mutant } \\
\text { alleles was also possible. Its sensitivity is so } \\
\text { high that one single mutant KRAS gene is } \\
\text { able to be detected among } 200,000 \text { normal } \\
\text { alleles. }\end{array}$ & $\begin{array}{l}\text { Detection of rare mutations of } \\
\text { KRAS gene in several cancer cell } \\
\text { lines on a single chip }\end{array}$ & $\begin{array}{c}\text { Droplet-based quanti- } \\
\text { tative PCR }\end{array}$ \\
\hline (Mousa et al., 2009) & $\begin{array}{l}\text { Estrogen levels in breast cancer patients } \\
\text { significantly increased in some stages and } \\
\text { can be considered as an indicator of disease } \\
\text { progression. }\end{array}$ & $\begin{array}{l}\text { Microchip-based determination } \\
\text { of the estrogen levels in the blood } \\
\text { and tissue samples of patients } \\
\text { with cancer. }\end{array}$ & $\begin{array}{l}\text { droplet-based estro- } \\
\text { gen detection assay }\end{array}$ \\
\hline (Sung et al., 2011) & $\begin{array}{l}\text { In the presence of fibroblasts, tumor } \\
\text { cells become more aggressive. Therefore } \\
\text { fibroblasts inhibitor drug have the potential } \\
\text { to prevent the cancer progression. }\end{array}$ & $\begin{array}{l}\text { Culture of cancer cell line MCF- } \\
\text { DCIS with fibroblasts in adjacent } \\
\text { laminars on a chip to determine } \\
\text { the significance of fibroblasts in } \\
\text { cancer biology and development. }\end{array}$ & $\begin{array}{l}\text { co-culture for study- } \\
\text { ing tumor progres- } \\
\text { sion }\end{array}$ \\
\hline (Kim et al., 2012) & $\begin{array}{l}\text { This system provides the possibility of } \\
\text { designing an efficient drug screening system } \\
\text { which contributes to control various cancers. }\end{array}$ & $\begin{array}{l}\text { The effect of different concen- } \\
\text { trations of sensitizer and death } \\
\text { inducer drugs on prostate cancer } \\
\text { cells in a } 64 \text {-well chip made of } \\
\text { PDMS. }\end{array}$ & $\begin{array}{l}\text { Cell culture microar- } \\
\text { ray }\end{array}$ \\
\hline (Chen et al., 2010) & $\begin{array}{l}\text { It was shown that there are various mRNAs } \\
\text { and miRNAs inside the micro-vesicles with a } \\
\text { little diversity in ribosomal RNA. Moreover, } \\
\text { it was deciphered that the micro-vesicle } \\
\text { levels in normal saliva are significantly } \\
\text { lower than patient saliva samples. It was } \\
\text { also indicated that mRNA levels of GAPDH } \\
\text { and IDH1 in both patients and normal group } \\
\text { is remarkably greater where the anti-CD63 } \\
\text { coated surfaces were used. }\end{array}$ & $\begin{array}{l}\text { Isolation of micro-vesicles } \\
\text { from saliva of patients with } \\
\text { glioblastoma multiform using } \\
\text { anti-CD63 coated surfaces, RNA } \\
\text { extraction from vesicles and } \\
\text { detection of point mutations; on a } \\
\text { multifunctional microchip. }\end{array}$ & $\begin{array}{l}\text { Exosome isolation } \\
\text { and RT-PCR analysis }\end{array}$ \\
\hline
\end{tabular}

Regarding the history of using microchips for cancer study purposes the following studies are among the pioneering efforts in this promising path: cDNA microarray for gene expression profiling of human cancers (1996) (DeRisi et al., 1996), molecular analysis of tumor cells using microchip technology (1998) (Pappalardo et al., 1998), chip-based gene expression profile of human melanoma cells (1999) (Huang et al., 1999), designing of chips for molecular diagnosis of lympho-proliferative disorders (Munro et al., 1999), designing a especial Lymphochip for gene expression profiling of different types of diffuse large B-cell lymphomas (DLBCL) 
Table 4. A List of the Most Important Exploitations and Studies in the Field of the Biology, Diagnosis, Treatment, and Monitoring of the Cancer Using Microchip Technology (Continued)

\begin{tabular}{|c|c|c|c|}
\hline (White et al., 2011) & $\begin{array}{l}\text { Heterogeneous expression was detected for } \\
\text { miR-223, miR-196a, and miR-145 in K562 } \\
\text { cell population. While miR-92 and miR-17- } \\
5 p \text { showed a uniform pattern of expression } \\
\text { in all the cells. In aim } 2 \text {, miR-145 showed } \\
20 \text { fold increases in expression and OCT4 } \\
\text { was down-regulated by } 30 \text { fold. Prevalence } \\
\text { of SP1 mutant allel for homozygote and } \\
\text { heterozygote forms was shown to comprise } \\
1 \% \text { and } 19 \% \text { of cell population, respectively. }\end{array}$ & $\begin{array}{l}\text { MiRNA expression profiling in } \\
\text { K562 cell line (aim1); expression } \\
\text { analysis of miR-145 and its main } \\
\text { targets during embryonic stem } \\
\text { cell differentiation (aim2); The } \\
\text { prevalence of mutant allel and } \\
\text { single nucleotide polymorphisms } \\
\text { (SNPs) of transcription factor SP1 } \\
\text { in metastatic breast cancer cells } \\
\text { (aim3) on a single microchip. }\end{array}$ & $\begin{array}{c}\text { Single-cell miRNA } \\
\text { expression analysis } \\
\text { By RT-quantitative } \\
\text { PCR }\end{array}$ \\
\hline $\begin{array}{l}\text { (Nasedkina et al., } \\
\text { 2014) }\end{array}$ & $\begin{array}{l}\text { Prevalent mutations were reported in } 8 \% \text { of } \\
\text { patients. BRCA1-5382incC and CHEK2- } \\
1100 \mathrm{delC} \text { mutations were detected in } \\
3.9 \% \text { and } 1.7 \% \text { of breast cancer patients, } \\
\text { respectively. }\end{array}$ & $\begin{array}{l}\text { Using microchips for mutation } \\
\text { analysis of BRCA1, BRCA2, and } \\
\text { CHEK2 genes patients with breast } \\
\text { cancer in Russia. }\end{array}$ & $\begin{array}{l}\text { Genotyping by Mi- } \\
\text { croarrays }\end{array}$ \\
\hline (Wang et al., 2015c) & $\begin{array}{l}\text { At first, HE } 4 \text { protein is absorbed to its special } \\
\text { destiny in chip, and after the primary and } \\
\text { secondary antibodies the specific substrate } \\
\text { is added. Finally, the color producing } \\
\text { reaction is occurred and the intensity of } \\
\text { color can be calculated by specific devices } \\
\text { or even cell phones. By using this chip HE4 } \\
\text { concentration in urine is determined thus the } \\
\text { early diagnosis of ovarian cancer becomes } \\
\text { possible. }\end{array}$ & $\begin{array}{l}\text { Detection of HE4 biomarker } \\
\text { using a specialized microchip in } \\
\text { urine samples of ovarian cancer } \\
\text { patients. }\end{array}$ & ELISA-based chips \\
\hline $\begin{array}{l}\text { (Zubcova Zh et al., } \\
\text { 2013) }\end{array}$ & $\begin{array}{l}\text { Several tumor markers were reported to be } \\
\text { up-regulated in } 77 \% \text { of patient's sera and } \\
6 \% \text { of normal sera. Simultaneous analysis of } \\
\text { multiple tumor markers represents a better } \\
\text { screening than single biomarker detection. }\end{array}$ & $\begin{array}{l}\text { Chip based simultaneous } \\
\text { detection of multiple tumor } \\
\text { markers including AFP, CEA, } \\
\text { HCG, CA 15-3, CA125, CA19- } \\
\text { 9, PSA, and NSE for efficient } \\
\text { screening of breast cancer. } \\
\end{array}$ & Immunoassay \\
\hline (Leng et al., 2014) & $\begin{array}{l}\text { Using PCR-Capillary Electrophoresis and } \\
\text { microchip, respectively } 32 \% \text { and } 27 \% \text { of } \\
\text { AML samples were reported as positive } \\
\text { for FLT3-ITD mutation. Statistical analysis } \\
\text { showed a desired precision and sensitivity } \\
\text { for the both methods. }\end{array}$ & $\begin{array}{l}\text { Comparison of two methods } \\
\text { (chip- and PCR capillary } \\
\text { electrophoresis-based) for AML } \\
\text { screening based on detection of } \\
\text { FLT3-ITD gene mutation. }\end{array}$ & $\begin{array}{l}\text { PCR-Microchip } \\
\text { Electrophoresis }\end{array}$ \\
\hline (Lin et al., 2013) & $\begin{array}{l}\text { In this study, using a combination of two } \\
\text { techniques on a single chip allowed the } \\
\text { high sensitive simultaneous detection of } \\
\text { two separate transcripts of the fusion gene } \\
\text { including b2a2 and b3a2. }\end{array}$ & $\begin{array}{l}\text { Design of specialized chip } \\
\text { technique to analyze the BCR- } \\
\text { ABL gene fusion for clinical } \\
\text { diagnosis of CML. }\end{array}$ & $\begin{array}{c}\text { RT-PCR \& } \\
\text { Electrophoresis }\end{array}$ \\
\hline $\begin{array}{l}\text { (Pilarski et al., } \\
\text { 2005) }\end{array}$ & $\begin{array}{l}\text { This strategy requires the minimum amounts } \\
\text { of starting sample ( } 5 \% \text { of that used in ABI- } \\
3100 \text { system). This tiny consumption also } \\
\text { associates with a remarkable precision } \\
\text { compared with macro-scale models, which } \\
\text { can facilitate the diagnosis of multiple } \\
\text { myeloma patients. }\end{array}$ & $\begin{array}{l}\text { Using microchips for precise } \\
\text { identification of IgH-VDJ } \\
\text { recombinant } \\
\text { multiple } \\
\text { planscripts in } \\
\text { plasmacells. }\end{array}$ & $\begin{array}{l}\text { Detection of singe } \\
\text { cell PCR products } \\
\text { by Capillary } \\
\text { Electrophoresis }\end{array}$ \\
\hline (Ziober et al., 2008) & $\begin{array}{l}\text { Simultaneous analysis of a panel of } 25 \text { genes } \\
\text { responsible for oral cancer was performed } \\
\text { using microchip on patient's saliva samples. } \\
\text { The diagnosis and screening were conducted } \\
\text { on the samples with greater rate of precision, } \\
\text { sensitivity, and reproducibility compared } \\
\text { with previous methods. }\end{array}$ & $\begin{array}{l}\text { Microchip-based screening and } \\
\text { diagnosis of oral cancer on the } \\
\text { saliva samples. }\end{array}$ & multiplex RT-PCR \\
\hline
\end{tabular}

and molecular-based classification of these disorders (Alizadeh et al., 2000), using an electrophoretic-based chip for rapid and accurate detecting of mutations in BRCA1/2 genes in breast cancer (2000) (Tian et al., 2000), and the tracing of carcino-embryonic antigen in human saliva samples for the diagnosis of colorectal cancer (2001) (Sato et al., 2001). In this regard, many targeted research studies have been carried out to date with successful results as summarized in Table 4. 
Table 4. A List of the Most Important Exploitations and Studies in the Field of the Biology, Diagnosis, Treatment, and Monitoring of the Cancer Using Microchip Technology (Continued)

\begin{tabular}{|c|c|c|c|}
\hline (Alley et al., 2010) & $\begin{array}{l}\text { After analyzing the results, a biantennary- } \\
\text { mono sialylated N-linked glycan and a } \\
\text { triantennary-trisialylated element were } \\
\text { proposed as two useful biomarkers for } \\
\text { detection of aggressive breast cancers. }\end{array}$ & $\begin{array}{l}\text { The introduction of a precise } \\
\text { micro-system to find the N-linked } \\
\text { glycan biomarkers in order to } \\
\text { better diagnosis of breast cancer. }\end{array}$ & $\begin{array}{c}\text { Reversed- } \\
\text { phase Liquid } \\
\text { Chromatography- } \\
\text { Mass Spectrometry }\end{array}$ \\
\hline $\begin{array}{l}\text { (Hestekin et al., } \\
\text { 2011) }\end{array}$ & $\begin{array}{l}\text { In less than ten minutes, the detection of } \\
\text { P53 gene mutation was performed with } \\
\text { the sensitivity of } 98 \% \text { and specificity of } \\
100 \% \text {. In this method, both DNA strands are } \\
\text { labeled, which leads to a clear increase in its } \\
\text { specificity. The chip which was designed for } \\
\text { this study, allowed the detection of all the } \\
\text { possible mutations in P53 gene exons. }\end{array}$ & $\begin{array}{l}\text { Designing a sensitive and accurate } \\
\text { method to evaluate a variety of } \\
\text { P53 gene mutations on one chip }\end{array}$ & $\begin{array}{l}\text { electrophoresis- } \\
\text { SSCP/HA }\end{array}$ \\
\hline $\begin{array}{l}\text { (Raamanathan et al., } \\
\text { 2012) }\end{array}$ & $\begin{array}{l}\text { The accuracy of the results in this study is } \\
\text { comparable with ELISA. This method is low } \\
\text { cost; it can be done in a short time; is able to } \\
\text { detect ovarian cancer in its early stages with } \\
\text { a high reproducibility. It is also suitable for } \\
\text { Point-of-care testing. }\end{array}$ & $\begin{array}{l}\text { Serum quantification of CA125 } \\
\text { for the diagnosis and monitoring } \\
\text { of ovarian cancer in the form of } \\
\text { a programmable bio-nano-chip } \\
\text { (p-BNC). }\end{array}$ & $\begin{array}{l}\text { fluorescence- } \\
\text { based sandwich } \\
\text { immunoassay }\end{array}$ \\
\hline (Shi et al., 2012) & $\begin{array}{l}\text { In this study, membrane and cytoplasmic } \\
\text { protein dosage as well as the profiling of } \\
\text { protein-protein interactions in the tumor } \\
\text { cells was determined. The system creates } \\
\text { a snapshot of the tumor cell signaling, and } \\
\text { understanding of cancer biology and drug } \\
\text { design to treat them more convenient than } \\
\text { the past. }\end{array}$ & $\begin{array}{l}\text { Using microfluid to study the } \\
\text { signaling pathways in a group of } \\
\text { tumor cells }\end{array}$ & $\begin{array}{l}\text { Single-cell } \\
\text { proteomics }\end{array}$ \\
\hline
\end{tabular}

\section{Conclusions and Future Perspectives}

According to the above mentioned concepts, using the circulating tumor cells (as the test sample) and small, cheap, reliable and portable microchips (as the test environment), the human being has taken a laudable step toward a more accurate monitoring of cancer. However in this path several challenges exist which are yet to be fully addressed.

One of the top limitations regarding the use of these micro-fluidic systems for cancer monitoring is their incapability to isolate the tiny amounts of CTCs from blood samples of patients with early stages of malignancies before the metastatic progression (it is ideal to isolate 5 tumor cells among 100 million blood cells). Undoubtedly, if the malignancy would be detectable in such early stages the chance for patients remission and survival reaches to its maximum state (Bunger et al., 2015). Prospectively, this problem also will able to be resolved using specialized and more efficient chip design as well as advanced materials. In this regard, effective strategies to increase the sensitivity of microchips have been also proposed (Chiu et al., 2015).

Identification of highly specific biomarkers with stable expression through which the tumor cells would be detectable in every stage of the disease can be a proper strategy to make these systems more efficient (Lianidou et al., 2015). Using novel biomarkers for CTC isolation as well as gene expression profiling can also help to pave the way toward a more desirable cancer monitoring (Lianidou et al.,2015). Another solution is to identify new prognostic biomarkers that are certainly best harbingers of the early stages of cancer, a principle which can be applied to prevent the metastasis formation. CA19, CA20 and PSCA are among these biomarkers (Muluneh and Issadore, 2014). Recently the creation of nanowires is considered a great success as a strategy which is capable of high throughput CTC isolation. These systems are specialized microchips for detection of small amounts of circulating tumor cells. These microchips contain several nanowires coated with monoclonal antibodies against specific biomarkers (Wang et al., 2015). Nanowires have been able to impressively increase the sensitivity of CTC isolation and herald a bright future in the early stage diagnosis of cancer (Wang et al., 2015).

As a real concern, nowadays what that many modern research laboratories take under study are still far from those which are required in practice and clinical trials. This means that the abundance of research data cannot be easily translated into clinic (Bean, 2001). This challenge has been slightly obviated by using microchips. Indeed, the simulation of in vivo environment into micro-fluidic systems is a cheaper, easier and faster than macro-scale models. Moreover, the results obtained from these systems can be easily attributed to real physiology of in vivo environment with high accuracy and sensitivity. In fact, using microchips and their ability to investigate the detailed layers of cellular and molecular interactions have been able to largely destroy the barrier between the research laboratory data and clinical practices (Bean, 2001).

As another main challenge regarding the microchips is that they extensively applied in the research levels while they are slightly used in routine clinical diagnosis. Using 
microchip as a versatile technique and its accessibility to all the personnel and specialists requires a huge investment and a consistent administrative policy. Undoubtedly, achieving this goal will be a big turn in routine diagnostic of various disorders especially for cancers (Kuo and Chiu, 2011). On the other hand along with the specialized micro-fluids used for detailed scrutiny of disorders, the design of micro-systems for point-of-care diagnosis allows the monitoring of malignancies much faster than the traditional methods $(\mathrm{Ng}$ and Wheeler, 2015). A modern derivative of chip systems which has facilitated the understanding of cancer biology is referred to as "Risk-on-a-chip" system. Recently this method has been utilized to predict the time when the breast cancer progressed toward a high-risk stage (Vidi et al., 2013). In this regard designing more specialized microchip systems for a broad range of human cancers would pave the way toward a great success in controlling of cancers before entering into their invasive stages.

Currently, exosomes have been proposed by many scientists as novel biomarkers for early detection of cancer formation ( $\mathrm{Li}$ et al., 2015). Macro-scale models for the purification and analysis of exosomes are labor intensive, time consuming, and expensive. They are also associated with a low accuracy and sensitivity and very difficult to be optimized. Furthermore, macro-scale systems demand large amount of samples, a requirement that is almost impossible about exosomes. The new generations of micro-systems have been successful to obviate these predicaments as they are able to analyze the exosomes in minute concentrations. These microchips have gained a huge volume of useful information about the mechanisms behind the biology of cancers; however this field is encountered with a great spectrum of ambiguities which requires more clarifications (Kanwar et al., 2014).

In a quick glance, several characteristics of a microchip can under shadow its overall functions which are include: the physics of the chip and its dimensions; material used in its synthesis; types of pumps, channels and valves; chip manufacturing technology; the type, quantity, quality and sample processing, reliability, standardization, precision and the sensitivity of chip for sampling, analysis and final recording of the results. In the near future each of these features might be a topic for different challenges and investigations. Conclusively, further development of ingeniously designed micro-systems, identification of proper materials with a high bio-compatibility for chip manufacturing, discovering novel biomarkers, optimizing the integration of various processes on a single platform, and using highly efficient bio-detectors in the structure of microchips can help to largely enhance the early diagnosis of human cancers. In fact, in the current scientific community which with the advent of modern technology and advanced equipments is rapidly developing, chip-based cancer monitoring like the other large research projects has been turned out to an extensive field of study and has been able to obviate many concerns regarding the human cancers and the related challenges. It is valuable to note that this trend is progressively going through forward which can bring promising achievements for health-care system.

\section{References}

Aitman TJ (2001). DNA microarrays in medical practice. $B M J$, 323, 611-5.

Alexis F, Rhee JW, Richie JP, et al (2008). New frontiers in nanotechnology for cancer treatment. Urol Oncol, 26, 74-85.

Alizadeh AA, Eisen MB, Davis RE, et al (2000). Distinct types of diffuse large B-cell lymphoma identified by gene expression profiling. Nature, 403, 503-11.

Allan AL, Keeney M (2010). Circulating tumor cell analysis: technical and statistical considerations for application to the clinic. J Oncol, 2010, 426218.

Allen-Mersh TG, McCullough TK, Patel H, et al (2007). Role of circulating tumour cells in predicting recurrence after excision of primary colorectal carcinoma. Br J Surg, 94, 96-105.

Azad M, Bakhshi Biniaz R, Goudarzi M, et al (2015). Short view of leukemia diagnosis and treatment in iran. Int J Hematol Oncol Stem Cell Res, 9, 88-94.

Backhouse CJ, Crabtree HJ, Glerum DM (2002). Frontal analysis on a microchip. Analyst, 127, 1169-75.

Bean P (2001). Biochips 2001: the second-generation chip for the clinic. Am Clin Lab, 20, 11-2.

Bhagat AA, Hou HW, Li LD, et al (2011). Pinched flow coupled shear-modulated inertial microfluidics for high-throughput rare blood cell separation. Lab Chip, 11, 1870-8.

Brivio M, Verboom W, Reinhoudt DN (2006). Miniaturized continuous flow reaction vessels: influence on chemical reactions. Lab Chip, 6, 329-44.

Brouzes E, Medkova M, Savenelli N, et al (2009). Droplet microfluidic technology for single-cell high-throughput screening. Proc Natl Acad Sci U S A, 106, 14195-200.

Bunger S, Zimmermann M, Habermann JK (2015). Diversity of assessing circulating tumor cells (CTCs) emphasizes need for standardization: a CTC Guide to design and report trials. Cancer Metastasis Rev, 34, 527-45.

Chen CL, Chen KC, Pan YC, et al (2011a). Separation and detection of rare cells in a microfluidic disk via negative selection. Lab Chip, 11, 474-83.

Chen KC, Lee TP, Pan YC, et al (2011b). Detection of circulating endothelial cells via a microfluidic disk. Clin Chem, 57, 586-92.

Chiu TK, Lei KF, Hsieh CH, et al (2015). Development of a microfluidic-based optical sensing device for label-free detection of circulating tumor cells (CTCs) through their lactic acid metabolism. Sensors (Basel), 15, 6789-806.

Chuang WC, Lee HL, Chang PZ, et al (2010). Review on the modeling of electrostatic MEMS. Sensors (Basel), 10, 6149-71.

Cibilic D (2000). Microchip action. Aust Vet J, 78, 598.

de Bono JS, Attard G, Adjei A, et al (2007). Potential applications for circulating tumor cells expressing the insulin-like growth factor-I receptor. Clin Cancer Res, 13, 3611-6.

den Toonder J (2011). Circulating tumor cells: the Grand Challenge. Lab Chip, 11, 375-7.

DeRisi J, Penland L, Brown PO, et al (1996). Use of a cDNA microarray to analyse gene expression patterns in human cancer. Nat Genet, 14, 457-60.

Dharmasiri U, Balamurugan S, Adams AA, et al (2009). Highly efficient capture and enumeration of low abundance prostate cancer cells using prostate-specific membrane antigen aptamers immobilized to a polymeric microfluidic device. Electrophoresis, 30, 3289-300.

Dharmasiri U, Njoroge SK, Witek MA, et al (2011). Highthroughput selection, enumeration, electrokinetic manipulation, and molecular profiling of low-abundance circulating tumor cells using a microfluidic system. Anal 
Chem, 83, 2301-9.

Di Carlo D, Wu LY, Lee LP (2006). Dynamic single cell culture array. Lab Chip, 6, 1445-9.

Dingwall R (1979). Are you ready for the microchip? Nurs Times, 75, 975-6.

Emmert-Buck MR, Bonner RF, Smith PD, et al (1996). Laser capture microdissection. Science, 274, 998-1001.

Fabian TK, Fejerdy P, Csermely P (2008). Salivary Genomics, Transcriptomics and Proteomics: The Emerging Concept of the Oral Ecosystem and their Use in the Early Diagnosis of Cancer and other Diseases. Curr Genomics, 9, 11-21.

Fey MF (2002). The impact of chip technology on cancer medicine. Ann Oncol, 13, 109-13.

Figeys D, Pinto D (2000). Lab-on-a-chip: a revolution in biological and medical sciences. Anal Chem, 72, 330A-5A.

Gleghorn JP, Pratt ED, Denning D, et al (2010). Capture of circulating tumor cells from whole blood of prostate cancer patients using geometrically enhanced differential immunocapture (GEDI) and a prostate-specific antibody. Lab Chip, 10, 27-9.

Gomez-Sjoberg R, Leyrat AA, Pirone DM, et al (2007). Versatile, fully automated, microfluidic cell culture system. Anal Chem, 79, 8557-63.

Goodale D, Phay C, Postenka CO, et al (2009). Characterization of tumor cell dissemination patterns in preclinical models of cancer metastasis using flow cytometry and laser scanning cytometry. Cytometry A, 75, 344-55.

Gross A, Schoendube J, Zimmermann S, et al (2015). Technologies for Single-Cell Isolation. Int J Mol Sci, 16, 16897-919.

Guzman NA, Phillips TM (2011). Immunoaffinity capillary electrophoresis: a new versatile tool for determining protein biomarkers in inflammatory processes. Electrophoresis, 32, 1565-78.

Helo P, Cronin AM, Danila DC, et al (2009). Circulating prostate tumor cells detected by reverse transcription-PCR in men with localized or castration-refractory prostate cancer: concordance with CellSearch assay and association with bone metastases and with survival. Clin Chem, 55, 765-73.

Holden C (1989). Engineers' nobel to microchip pioneers. Science, 246, 214.

Hosokawa M, Hayata T, Fukuda Y, et al (2010). Size-selective microcavity array for rapid and efficient detection of circulating tumor cells. Anal Chem, 82, 6629-35.

Huang F, Adelman J, Jiang H, et al (1999). Identification and temporal expression pattern of genes modulated during irreversible growth arrest and terminal differentiation in human melanoma cells. Oncogene, $\mathbf{1 8}, 3546-52$.

Hung LY, Chuang YH, Kuo HT, et al (2013). An integrated microfluidic platform for rapid tumor cell isolation, counting and molecular diagnosis. Biomed Microdevices, 15,339-52.

Hur SC, Henderson-MacLennan NK, McCabe ER, et al (2011). Deformability-based cell classification and enrichment using inertial microfluidics. Lab Chip, 11, 912-20.

Kang JH, Krause S, Tobin H, et al (2012). A combined micromagnetic-microfluidic device for rapid capture and culture of rare circulating tumor cells. Lab Chip, 12, 2175-81.

Kanwar SS, Dunlay CJ, Simeone DM, et al (2014). Microfluidic device (ExoChip) for on-chip isolation, quantification and characterization of circulating exosomes. Lab Chip, $\mathbf{1 4}$ 1891-900.

Kartalov EP, Zhong JF, Scherer A, et al (2006). High-throughput multi-antigen microfluidic fluorescence immunoassays. Biotechniques, 40, 85-90.

Kim H, Lee S, Lee JH, et al (2015). Integration of a microfluidic chip with a size-based cell bandpass filter for reliable isolation of single cells. Lab Chip, 15, 4128-32.
Kim YJ, Koo GB, Lee JY, et al (2014). A microchip filter device incorporating slit arrays and 3-D flow for detection of circulating tumor cells using CAV1-EpCAM conjugated microbeads. Biomaterials, 35, 7501-10.

Kuo JS, Chiu DT (2011). Disposable microfluidic substrates: transitioning from the research laboratory into the clinic. Lab Chip, 11, 2656-65.

Kuo JS, Zhao Y, Schiro PG, et al (2010). Deformability considerations in filtration of biological cells. Lab Chip, 10, 837-42.

Li Y, Zheng Q, Bao C, et al (2015). Circular RNA is enriched and stable in exosomes: a promising biomarker for cancer diagnosis. Cell Res, 25, 981-4.

Lianidou ES, Markou A, Strati A (2015). The Role of CTCs as Tumor Biomarkers. Adv Exp Med Biol, 867, 341-67.

Liu RH, Yang J, Lenigk R, et al (2004). Self-contained, fully integrated biochip for sample preparation, polymerase chain reaction amplification, and DNA microarray detection. Anal Chem, 76, 1824-31.

Mach AJ, Adeyiga OB, Di Carlo D (2013). Microfluidic sample preparation for diagnostic cytopathology. Lab Chip, 13, 1011-26.

Maheswaran S, Haber DA (2010). Circulating tumor cells: a window into cancer biology and metastasis. Curr Opin Genet Dev, 20, 96-9.

Maheswaran S, Sequist LV, Nagrath S, et al (2008). Detection of mutations in EGFR in circulating lung-cancer cells. $N$ Engl J Med, 359, 366-77.

Mair DA, Geiger E, Pisano AP, et al (2006). Injection molded microfluidic chips featuring integrated interconnects. $\mathrm{Lab}$ Chip, 6, 1346-54.

Marques MP, Fernandes P (2011). Microfluidic devices: useful tools for bioprocess intensification. Molecules, 16, 8368-401.

Meng S, Tripathy D, Shete S, et al (2004). HER-2 gene amplification can be acquired as breast cancer progresses. Proc Natl Acad Sci U S A, 101, 9393-8.

Meng S, Tripathy D, Shete S, et al (2006). uPAR and HER-2 gene status in individual breast cancer cells from blood and tissues. Proc Natl Acad Sci U S A, 103, 17361-5.

Minhas H (2015). Developing the Lab on a Chip-microTAS community. Lab Chip, 15, 15-6.

Moon HS, Kwon K, Kim SI, et al (2011). Continuous separation of breast cancer cells from blood samples using multi-orifice flow fractionation (MOFF) and dielectrophoresis (DEP). Lab Chip, 11, 1118-25.

Mrksich M, Whitesides GM (1996). Using self-assembled monolayers to understand the interactions of man-made surfaces with proteins and cells. Annu Rev Biophys Biomol Struct, 25, 55-78.

Muluneh M, Issadore D (2014). Microchip-based detection of magnetically labeled cancer biomarkers. Adv Drug Deliv Rev, 66, 101-9.

Munro NJ, Snow K, Kant JA, et al (1999). Molecular diagnostics on microfabricated electrophoretic devices: from slab gelto capillary- to microchip-based assays for T- and B-cell lymphoproliferative disorders. Clin Chem, 45, 1906-17.

Myung JH, Launiere CA, Eddington DT, et al (2010). Enhanced tumor cell isolation by a biomimetic combination of E-selectin and anti-EpCAM: implications for the effective separation of circulating tumor cells (CTCs). Langmuir, 26, 8589-96.

Nagrath S, Sequist LV, Maheswaran S, et al (2007). Isolation of rare circulating tumour cells in cancer patients by microchip technology. Nature, 450, 1235-9.

Nandi P, Lunte SM (2009). Recent trends in microdialysis sampling integrated with conventional and microanalytical systems for monitoring biological events: a review. Anal 


\section{Mehdi Sahmani et al} Chim Acta, 651, 1-14.

$\mathrm{Ng} \mathrm{AH,} \mathrm{Wheeler} \mathrm{AR} \mathrm{(2015).} \mathrm{Next-generation} \mathrm{microfluidic} \mathrm{point-}$ of-care diagnostics. Clin Chem, 61, 1233-4.

Nge PN, Rogers CI, Woolley AT (2013). Advances in microfluidic materials, functions, integration, and applications. Chem Rev, 113, 2550-83

Nind F (1999). Microchip identification. Vet Rec, 145, 532.

Pantel K, Brakenhoff RH, Brandt B (2008). Detection, clinical relevance and specific biological properties of disseminating tumour cells. Nat Rev Cancer, 8, 329-40.

Pappalardo PA, Bonner R, Krizman DB, et al (1998). Microdissection, microchip arrays, and molecular analysis of tumor cells (primary and metastases). Semin Radiat Oncol, 8, 217-23.

Payne RE, Yague E, Slade MJ, et al (2009). Measurements of EGFR expression on circulating tumor cells are reproducible over time in metastatic breast cancer patients. Pharmacogenomics, 10, 51-7.

Ratajczak J, Wysoczynski M, Hayek F, et al (2006). Membranederived microvesicles: important and underappreciated mediators of cell-to-cell communication. Leukemia, $\mathbf{2 0}$, 1487-95.

Reyes DR, Iossifidis D, Auroux PA, et al (2002). Micro total analysis systems. 1. Introduction, theory, and technology. Anal Chem, 74, 2623-36.

Saliba AE, Saias L, Psychari E, et al (2010). Microfluidic sorting and multimodal typing of cancer cells in self-assembled magnetic arrays. Proc Natl Acad Sci U S A, 107, 14524-9.

Sato K, Tokeshi M, Kimura H, et al (2001). Determination of carcinoembryonic antigen in human sera by integrated beadbed immunoassay in a microchip for cancer diagnosis. Anal Chem, 73, 1213-8.

Sato K, Yamanaka M, Takahashi H, et al (2002). Microchipbased immunoassay system with branching multichannels for simultaneous determination of interferon-gamma. Electrophoresis, 23, 734-9.

Seemann R, Brinkmann M, Pfohl T, et al (2012). Droplet based microfluidics. Rep Prog Phys, 75, 016601.

Seigneuric R, Markey L, Nuyten DS, et al (2010). From nanotechnology to nanomedicine: applications to cancer research. Curr Mol Med, 10, 640-52.

Sheng W, Ogunwobi OO, Chen T, et al (2014). Capture, release and culture of circulating tumor cells from pancreatic cancer patients using an enhanced mixing chip. Lab Chip, 14, 89-98.

Sin ML, Gao J, Liao JC, et al (2011). System Integration - A Major Step toward Lab on a Chip. J Biol Eng, 5, 6.

Smith RJ (1984). Pentagon hit by new microchip troubles. Science, 226, 953.

Stathopoulou A, Gizi A, Perraki M, et al (2003). Real-time quantification of CK-19 mRNA-positive cells in peripheral blood of breast cancer patients using the lightcycler system. Clin Cancer Res, 9, 5145-51.

Stott SL, Hsu CH, Tsukrov DI, et al (2010). Isolation of circulating tumor cells using a microvortex-generating herringbone-chip. Proc Natl Acad Sci U S A, 107, 18392-7.

Taylor DD, Gercel-Taylor C (2005). Tumour-derived exosomes and their role in cancer-associated T-cell signalling defects. Br J Cancer, 92, 305-11.

Tian H, Jaquins-Gerstl A, Munro N, et al (2000). Singlestrand conformation polymorphism analysis by capillary and microchip electrophoresis: a fast, simple method for detection of common mutations in BRCA1 and BRCA2. Genomics, 63, 25-34.

Tsujiura M, Ichikawa D, Komatsu S, et al (2010). Circulating microRNAs in plasma of patients with gastric cancers. $\mathrm{Br}$ J Cancer, 102, 1174-9.

Van Loo P, Voet T (2014). Single cell analysis of cancer genomes.
Curr Opin Genet Dev, 24, 82-91.

Vidi PA, Leary JF, Lelievre SA (2013). Building risk-on-achip models to improve breast cancer risk assessment and prevention. Integr Biol, 5, 1110-8.

Wang C, Ye M, Cheng L, et al (2015). Simultaneous isolation and detection of circulating tumor cells with a microfluidic silicon-nanowire-array integrated with magnetic upconversion nanoprobes. Biomaterials, 54, 55-62.

Wang J, Chen J, Sen S (2016). MicroRNA as Biomarkers and Diagnostics. J Cell Physiol, 231, 25-30.

Whitesides GM (2006). The origins and the future of microfluidics. Nature, 442, 368-73.

Whitesides GM, Ostuni E, Takayama S, et al (2001). Soft lithography in biology and biochemistry. Аnnu Rev Biomed Eng, 3, 335-73.

Wu A, Wang L, Jensen E, et al (2010). Modular integration of electronics and microfluidic systems using flexible printed circuit boards. Lab Chip, 10, 519-21.

Xi L, Nicastri DG, El-Hefnawy T, et al (2007). Optimal markers for real-time quantitative reverse transcription PCR detection of circulating tumor cells from melanoma, breast, colon, esophageal, head and neck, and lung cancers. Clin Chem, 53, 1206-15.

Yang J, Vykoukal J, Noshari J, et al (2000). DielectrophoresisBased Microfluidic Separation and Detection Systems. Int $J$ Adv Manuf Syst, 3, 1-12.

Yang J, Weinberg RA (2008). Epithelial-mesenchymal transition: at the crossroads of development and tumor metastasis. Dev Cell, 14, 818-29.

Zhang P, Sun C, Zhang R, et al (2013). A novel and facile microchip based on nitrocellulose membrane toward efficient capture of circulating tumor cells. Se Pu, 31, 518-21 (in Chinese).

Zhang Z, Nagrath S (2013). Microfluidics and cancer: are we there yet? Biomed Microdevices, 15, 595-609.

Zhao L, Lu YT, Li F, et al (2013). High-purity prostate circulating tumor cell isolation by a polymer nanofiber-embedded microchip for whole exome sequencing. Adv Mater, 25, 2897-902.

Zheng S, Lin H, Liu JQ, et al (2007). Membrane microfilter device for selective capture, electrolysis and genomic analysis of human circulating tumor cells. J Chromatogr $A, \mathbf{1 1 6 2}, 154-61$.

Zheng S, Lin HK, Lu B, et al (2011). 3D microfilter device for viable circulating tumor cell (CTC) enrichment from blood. Biomed Microdevices, 13, 203-13.

Zubritsky E (1999). Science: microchip gets a tip. Anal Chem, 71, 590-1 